Article

\title{
Toward Improved Adoption of Best Management Practices (BMPs) in the Lake Erie Basin: Perspectives from Resilience and Agricultural Innovation Literature
}

\author{
Cherine Akkari ${ }^{1, *}$ and Christopher Robin Bryant ${ }^{2}$ \\ 1 Department of Geography and Environmental Management, University of Waterloo, EV1-246, \\ Waterloo, ON N2L 3G1, Canada \\ 2 School of Environmental Design and Rural Planning, Landscape Architecture Bldg., University of Guelph, \\ Guelph, ON N1G 2W1, Canada; christopher.robin.bryant@gmail.com \\ * Correspondence: cherine.akkari@hotmail.com; Tel.: +1-(514)-699-4328
}

Academic Editors: Rabin Bhattarai and Paul Davidson

Received: 6 May 2017; Accepted: 30 June 2017; Published: 6 July 2017

\begin{abstract}
Phosphorus (P) runoff from agricultural sources is a recognized environmental problem, particularly in regions draining into Lake Erie. This problem may well be exacerbated particularly through increased magnitude and frequency of extreme climatic events (e.g., excessive precipitation and droughts). On the physical sciences side, the recent extensive literature focuses on structural Best Management Practices (BMPs) which have the potential to mitigate both surface and sub-subsurface P losses. Modeling studies show that there is still a lack of adoption of these P-related voluntary BMPs by the farmers. At the same time, and while the social sciences side of the literature on structural BMPs adoption weakly affirms the latter, this paper argues that the literature on resilience and on agricultural innovation can better inform our understanding of the limited adoption of phosphorus related structural BMPs by farmers in the Lake Erie Basin.
\end{abstract}

Keywords: agricultural phosphorus; resilience; best management practices (BMPs); agricultural innovation; Lake Erie

\section{Introduction}

Lake Erie is the southernmost of the five Laurentian Great Lakes that form a portion of the border between the USA and Canada. It is biologically the most active and the shallowest of the Great Lakes, as well as being the warmest and the most susceptible to eutrophication [1,2]. Together these characteristics make Lake Erie very susceptible to the effects of extreme climatic events (i.e., excessive precipitation and drought). Harmful and nuisance algal blooms (HNABs) have become more prevalent with the major contributing factor being the mass soluble phosphorus $(\mathrm{P})$ loadings due to agricultural runoff during large rain events (i.e., severe spring precipitation events especially during the March-to-June time-frame) [3-5]. Phosphorus levels in the eastern basin of Lake Erie currently meet target levels and are classified as good [6]. On the other hand, in the western and central basin of Lake Erie, phosphorus levels are above water quality objectives. Since 1970, phosphorus levels have been declining except for the central basin of Lake Erie, where they have not been changing [6]. Moreover, due to the role of phosphorus (i.e., DRP, dissolved reactive phosphorous) in eutrophication, $\mathrm{P}$ loss from agricultural drainage basins (also known as a type of non-source pollution) has been the major contributor to high phosphorus concentrations in water levels [7,8]. According to [9], about $63 \%$ of the lake's watershed is used for agriculture (e.g., the Maumee River, with agricultural dominated land use, is the largest tributary of the Western Lake Erie Basin [2]). It should be kept in mind that 
there are other sources that contribute to phosphorous loadings into Lake Erie, such as atmospheric deposition, direct point sources, and indirect point sources [10].

Compounded by excessive rain events, phosphorus loading represents a serious problem. Precipitation patterns in the Lake Erie Basin are characterized by less frequent but more intense storms [9]. Such intense events lead to higher nutrient runoff from agricultural lands, and increased overall nutrient loads to Lake Erie. Depending on the timing of runoff, future nutrient loading, coupled with warmer water temperatures, could lead to an increase in the severity and frequency of algal blooms [9]. In addition, the majority of $\mathrm{P}$ losses occurs during the non-growing season portion of the year [11]. This means that farming practices that leave the soil unprotected during the non-growing season are the major cause of the P losses. At the same time, it is very important to note that farming is becoming more intense (e.g., livestock farming and a greater application of their waste to fields, a higher application of fertilizers in general, and an increase in corn farming in the U.S. Midwest partly to meet a demand for ethanol fuel). Chung, (2014). Fischer (2014), King et al. (2015), and Smith et al. (2015) [1,11-13] have noted that on average, nearly $50 \%$ of both dissolved-bioavailable phosphorus and total phosphorus left fields via the tile system in the Midwestern United States in 2014. As a result, it has become imperative that farmers in the Lake Erie basin use conservation practices such as BMPs to minimize P loadings.

The relevant agricultural region discussed in this paper is focused on Ontario as well as that part of the United States that border Lake Erie. More specifically, it analyzes the adoption of structural BMPs that plays an important role in mitigating phosphorous runoff from croplands and livestock. It first starts by reviewing case studies that used modeling land management practices on watershed yields in relation to climate change to show that the adoption of structural BMPs is still limited. It then discusses the social factors that affect the adoption of such practices. Finally, it shows how the literatures on resilience and agricultural innovation can better inform us on the limited adoption of BMPs while bringing some insights to the issue.

\section{Current Modeling Studies}

Ross et al. [14] assessed the effectiveness of drainage water management (DWM), a type of structural BMP, on crop production in the United States using a multiple linear regression approach and concluded that DWM is effective in reducing water discharge and nutrient losses via tile drains. Similarly, Keitzer et al. [15] used hydrological simulation models throughout the western Lake Erie Basin (WLEB) watershed and found out that conservations practices like structural BMPs need to be implemented on farms' land acreage in critical and moderate need of treatment, representing half of the watershed, to achieve acceptable water levels. As a result, Keitzer et al. (2016) [15] added that the implementation of structural BMPs need to be widespread within the WLEB watershed, which means that there is enough widespread uptake of structural BMPs. This idea is also supported by Scavia et al. [10]. In addition, Yen et al. [16] used complex watershed simulation models (e.g., SWAT-Soil and Water Assessment Tool) to demonstrate the effects of structural practices on treatment scenarios. The authors deduced that it is more important to tackle treatment to farm acres with critical conservation needs since they provide the largest return on investment in terms of nutrient loss reduction, compared to farm acres in good conditions. Moreover, Scavia et al. [10] used five configured but separate SWAT models to assess load reduction strategies in the Maumee River watershed. The authors concluded that there is a need for large-scale implementation of multiple structural best management practices (e.g., subsurface application of $P$ fertilizers, planting cereal rye as a winter cover crop, and installation of buffer strips, to target $50 \%$ of row cropland that has the highest $\mathrm{P}$ loss in the watershed). The argument of using multiple practices has also been confirmed by Chiang et al. [17] (e.g., through using a combination of a multi-objective genetic algorithm and a SWAT model to select an optimum BMP among 171 BMP scenarios for livestock farms in the Lincolin Lake watershed). 


\section{Social Factors that Affect the Adoption of Structural BMPs}

As stated earlier, best management practices are known to effectively-economically and environmentally—reduce water quality impacts (e.g., [17]). To encourage farmers to adopt these practices, the federal governments in Canada and the United States have developed several incentives and initiatives (e.g., Agriculture and Agri-Food Canada, and the Environmental Quality Incentives Program-EQIP-in the United Sates). In Canada-Ontario for instance, WEBs (Watershed Evaluation of Beneficial Watershed Practices) evaluate the environmental and economic performance of BMPs at a smaller watershed scale [18]. As a result, when farmers implement these practices, they will receive technical assistance, cost-share payments and/or incentive payments. Kim et al. [19] undertook a probit analysis for the adoption of structural best management practices in beef cattle production and concluded that farmers are more willing to adopt such practices when their farms are more diversified. The other less important factors are shown in Table 1. Additionally, the authors summarized the socioeconomic factors that lead to the adoption of a rotational grazing system. By order of importance, these factors are: (1) higher bid offers; (2) farm succession; (3) age (i.e., older farmers are less likely to adopt such practices); (4) debt; and (5) geographical location.

Table 1. Factors affecting the adoption of best management practices in beef cattle production, by order of importance, according to [19].

\begin{tabular}{c}
\hline $\begin{array}{c}\text { Socioeconomic Factors the Adoption of BMPs } \\
\text { Farm's diversification }\end{array}$ \\
\hline $\begin{array}{c}\text { Social networks (e.g., increased contact with Natural Resources Conservation Service, } \\
\text { and Louisiana Cooperative Extension Service) }\end{array}$ \\
\hline Being near a stream or a river running through the farm \\
\hline Farmer's education level \\
\hline Famer's income \\
\hline Biophysical factors (i.e., slope)
\end{tabular}

Given that there are several factors that limit the adoption of BMPs, the abatement costs also play an important role. However, there are few studies on such economic factors, or at least they are not regularly being studied. Rao et al. [20] examined the water quality as well as the economic consequences of selected structural BMPs. The authors showed that not only converting run-off prone agricultural land to buffers and installing barnyard BMPs are both highly effective in decreasing dissolved $P$ from a single watershed, but they are also costly to the farmer. Agriculture and Agri-Food [18] evaluated the BMP performance at nine watersheds across Canada, including Ontario. The BMPs within WEBs were chosen mainly because of their potential to minimize agricultural runoff from surface and groundwater (Table 2). The report concluded that most BMPs require significant investment to implement and/or may increase operational cost through ongoing maintenance (e.g., fencing, crop rotations, off-stream livestock watering). On the other hand, however, these costs may be offset through some on-farm financial benefits (e.g., cattle exclusion fencing with off-stream watering may increase pasture utilization while providing high water quality to cattle) [18].

Table 2. Types of structural BMPs used within WEBs [18].

\begin{tabular}{cc}
\hline Classification of Structural BMPs Used within WEBs & Structural BMPs \\
\hline Riparian & Cattle exclusion fencing and off-stream watering \\
& Off-stream watering without fencing \\
Riparian vegetation management
\end{tabular}


Table 2. Cont.

\begin{tabular}{cc}
\hline Classification of Structural BMPs Used within WEBs & Structural BMPs \\
\hline In-Field & Winter bale-grazing \\
& Irrigation efficiency \\
\hline & Diversion terraces and grassed waterways \\
Runoff/discharge & Surface runoff control measures \\
& Buffer strips \\
& Farmyard runoff management \\
& Runoff retention pond \\
& Small reservoirs \\
\hline
\end{tabular}

\section{Insights from the Resilience Lens}

"Resilience has multiple levels of meaning — as a metaphor related to sustainability, as a property of dynamic models, and as a measurable quantity that can be assessed in field studies of SES" (socio-ecological system, which consists of a bio-geo-physical unit along with its associated social units) [21]. Along with the substantial research on ecosystem services, the term "resilience" is often used to describe features that are related to sustainability [21]. While resilience science is not new, attempts to apply it in real-world situations have only recently started to take place [22]. Concepts related to resilience are used in all disciplines; however, the term has only four main origins-psychological, ecological, disaster relief (and military), and engineering [22]. The ecological origin, which is the closest to the topic of this article, describes resilience in two ways: (a) one focused on whether or not the system can recover; and (b) the other one focused on the speed of return following a disturbance [22]. Therefore, resilience is "the capacity of a system to absorb disturbance and reorganize so as to retain essentially the main function, structure, and feedbacks-to have the same identity" [22]. However, these two characteristics are still not enough (e.g., they do not take into account the relocation of human settlement along with the ability to do so-this can be considered as part of resilience and may include the relocation of human activities for instance when severe flooding and tidal surges occur). As $\mathrm{O}^{\prime}$ Connell et al. [23] adds to this last point, resilience is also "the ability to build and increase the capacity for learning and adaptation, and the capacity to transform part of or all of the system into a different one when the existing one is in an irreversibly undesired state."

At the theoretical level in the resilience literature, the main question asked is how do we measure resilience? In other words, what are the indicators of resilience (e.g., Hammond, 2011; Schipper and Langston [24])? In relation to this question, there have been two main concepts which particularly bring insights to the literature on the adoption of BMPs. First, systems thinking has been the result of the increased recognition that complex environmental problems must be analyzed in an interdisciplinary manner in order to examine the interaction between social and ecological systems and the conditions of their equilibrium (i.e., human interaction between each other and its consequences on nature, or vice versa) [25]. Systems thinking is also known as a multidisciplinary or holistic approach. It is a management discipline concerned with examining all the linkages of a system. Consequently, and while various studies have explicitly considered the interaction between social and ecological systems, conceptual frameworks have been also developed to structure research on SES at the same time (e.g., Ostrom, 2007; 2009; Scholz, 2011; Epstein et al. [26-29]). For instance, Binder et al. [30] reviewed 10 major conceptual frameworks, characterizing socio-ecological system (SES) as the most comprehensive concept for structuring a research framework. According to their classification of SES frameworks, the farm is considered as a human-environment system (HES). Within this framework, the ecological system is presented in less detail compared to the social system, where it is only considered from an anthropocentric perspective. It considers the ecological system as a system coupled to the social system, whereby the framework suggests starting research with an understanding of the environmental problem [30]. However, the HES framework only takes environmental awareness into consideration as being the main determinant or social factor affecting decision making (awareness of an issue alone is not enough to predict behavior). This represents a bias with a strong influence in 
much SES resilience thinking [31]. In addition, this framework shows that while progress has been made in interdisciplinary investigations during the last decade, it is yet to flourish. For instance, systems approaches are still not dominant in the social sciences [32]. Furthermore, there is a general absence of ecological considerations within the SES framework [32].

Second, studies on resilience indicators indicate that learning is the most dominant theme in both the recommended indicators themselves and the approach used to develop resilience indicators [23]. The ability of people to access information and act accordingly is a major component of resilience [33]. Learning is about gaining greater and profound knowledge and awareness about the risk and its attributes [33]. This makes knowledge and awareness an important determinant of the adoption of BMPs. Without knowledge and awareness for instance, farmers will not be able to make effective decisions about whether to adopt the appropriate BMP. In fact, awareness and interest in acquiring more information are the two first stages of the process which producers commonly go through in adopting a practice [34]. Learning is also about the ability to incorporate lessons into preparedness (and recovery) or practice [35]. This suggests that farmers should test what they have learned-how the practice can be applied to the producer's production ('evaluation') in general, and at a specific site ("trial") [36]. In addition, learning also includes the ability to share the information with others so that they can assess the reliability and usefulness of the information according to their own requirements [37]. For example, when farmers see their neighboring farmers adopting a successful practice, either they will follow the practice or adjust their current practices accordingly (e.g., Kofinas and Chapin [38]). The best type of responses to the "surprise" is a response with experience-i.e., when social learning has gained insights from previous experiences [39]. This mainly happens through the sharing of knowledge gained from individuals learning through groups, organizations and networks. Hence, social learning is very important as it increases the likelihood of the system responding through experience and understanding of system dynamics [38]. It can also occur in many ways, e.g., through scientific research or by reading or by listening to the experience of others, or through the cumulative experience gained as local knowledge by observing, managing and coping with uncertainty and surprise [38]. As a result, local knowledge is crucial for a successful implementation of new solutions since it provides information about local conditions or context and it incorporates people's sense of place [38].

At the empirical level in the resilience literature, usually in the resilience assessment literature, researchers usually tend to describe the system of interest in five steps [23]. These critical questions are: (1) What is our system of interest, at what scale do we intend to define it (or focal scale), and what are the other scales that it is linked to?; (2) Who are the users of the systems (e.g., citizens and actors in governance systems)?; (3) Resilience of what? (What do people value and what are the biggest issues)?; (4) Resilience to what (disturbances to the system)?; and (5) What were and what are now the drivers of the system. These questions overlap and can be dealt with in any order (e.g., Grigg et al., 2015; O'Connell et al., 2015, [23,40]). Unlocking these questions using a resilience lens, through a resilience assessment (or a resilience approach to management), principally involves the development of adaptive policy (governance) and adaptive management [23] (Walker and Salt, 2012, Chapter 9), which can bring some lessons to the adoption of BMPs.

A resilience assessment starts with bringing together the stakeholders-the people with an interest or a stake in the system, and the people with the required knowledge. This requires an adaptive management framework [23]. Adaptive management is defined as learning-by-doing in a scientific way in order to deal with uncertainty [41]. Conventional centralized or top-down management is ill-suited for user participation, and is often the reason behind increased vulnerability of resource-dependent communities worldwide [42,43] (Similarly, given the complexity in the direction and magnitude of factors controlling socio-ecological systems, an adaptive management requires a flexible approach to governance that promotes collaboration among stakeholders at different scales and facilitates (social) learning (Kofinas, 2009 [38]). Governance is a combination of institutions (formal and informal rules including constitutions, laws, regulations, policies, and norms, that meditate interactions 
among people, between people, and their environments) and organizations, social networks, and the social and political processes (e.g., negotiations, information, incentives, coercion, and penalties) through which the rules are implemented [23]. Governance involves citizens, private and public organizations, as well as governments, and it operates at multiple scales [23]. Socio-ecological governance is the collective coordination of efforts to define and achieve societal goals related to human-environment interaction [44] (Young, 2008). In order to achieve adaptive management for resilience, governance itself needs to be adaptive $[23,45]$. A governance process is adaptive "when it changes in anticipation of or in response to new circumstances, problems, or opportunities" [23]. Any form of non-adaptive governance of a dynamic system with changing thresholds, is destined to become a failed governance process [23]. For instance, a command-and-control approach to management usually focuses on ecological and environmental controls and sees human behavior as exogenous to ecosystems. Consequently, this can lead to a limited trust relationship as the top-down approach can be insensitive and unresponsive to local conditions, human livelihoods, and community concerns [46]. If users (farmers) are not involved in a program, they will often not adopt a recommended practice.

As a result, the co-management approach has emerged. It is primarily concerned with user participation in decision-making and linking communities and government managers together [41]. It implies the sharing of rights and responsibilities by the government and civil society [47] (Plummer and FitzGibbon, 2004). Co-management has evolved as a formalized management strategy with which to link local communities and governments [41]. And some of these arrangements are codified in laws such as the various indigenous land and various resource rights cases in the United States, Canada, Australia, and New Zealand [41]. Nonetheless, an inappropriate bottom-up approach in management is also doomed to fail. Adoption of a certain practice might not last long in that case. [48] Bastakoti et al. (2010) found that many water user groups failed once government support ended. Indeed, adaptive management is a learning approach that focuses on policy (through governance) and practice (through learning-by-doing) under uncertainty [41]. The "one-size does-not-fit-all" approach is an inherent characteristic of adaptive management, in which "management strategies and policies are considered experiments and learning is encouraged through both structured experiments and management flexibility" [41]. So, in order for a BMP to be adaptive in the long-run, it needs to employ an adaptive management approach that integrates the concepts of adaptive governance and co-management (Figure 1), leading to a successful and wider adoption by farmers. The idea of collaborative or cooperative management is gaining attention as policy makers and decision makers are realizing that systematic learning and innovation under conditions of uncertainty are more likely the results of meaningful interaction of stakeholders [41].

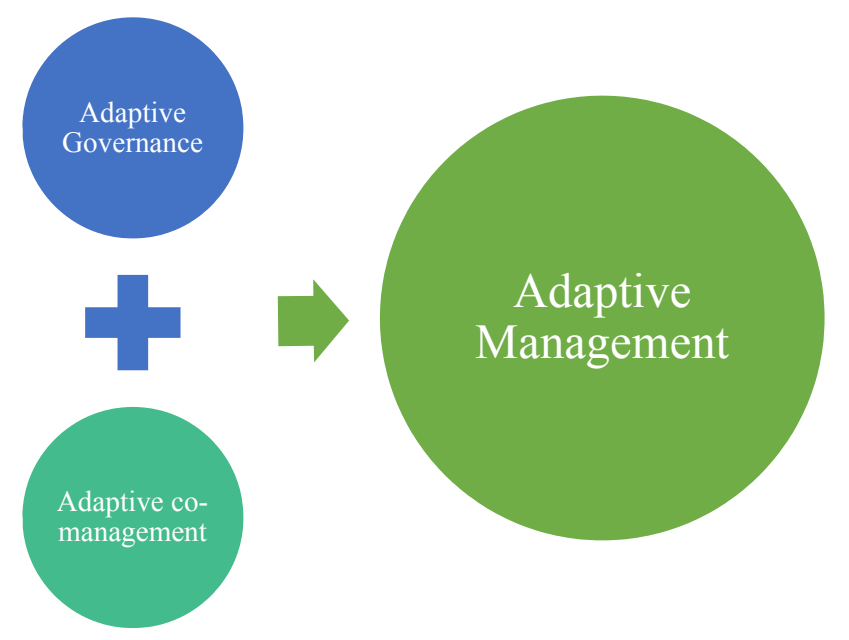

Figure 1. Adaptive management relies on adaptive governance and co-management. 


\section{Innovation in Agriculture and Knowledge Circulation}

For a long time (1960s and onwards), since the expansion of industrial food and agriculture, innovation often equaled the development, transfer and adoption of single-component technologies such as new crop varieties or agrochemicals) $[49,50]$. This led to increased negative consequences or externalities for food safety, public health and the environment, especially soil erosion and water pollution [51]. As a result, there has been a shift from technology-oriented approaches to more systems-oriented approaches [49] (even in the geography of innovation literature, an additional development has been an expansion of the object of study from science-based innovations to experienced-based innovations [52]).

As a result, agricultural innovation is now recognized as a complex system covering technological and institutional changes that some researchers term as being social innovation or systems of innovations (e.g., Klerkx et al., 2012; Daouda and Bryant, 2015; Schut et al., 2014; 2015 [49,53-55]). Sunding and Zilberman [56] stated that "innovations-new ways to perform tasks, new products and new procedures-are the elements of institutional and technological change." Taylor et al. [57] defines innovations as human adaptations to changing needs and socio-economic conditions, and are therefore embedded in social processes. Similarly, technological innovation in agriculture is now being termed as induced innovation, where institutions play an important role in the innovation process [57]. As a result of the shift to systems of innovations, not only the role of agricultural advisory services (AAS) has changed to accommodate different organizational reforms and methods so as to best fit local circumstances, but their importance is being increasingly recognized as they are heavily integrated into agricultural innovation systems (AIS) in which knowledge and innovations are generated, disseminated and used in the agricultural sector. Specifically, the concept of an agricultural knowledge and information system (AKIS) implies the integration of agricultural research, agricultural extension, and agricultural education, whereas the concept of AIS implies a wider range of organizations and stakeholders involved in agricultural innovations along with agricultural value chains (Figure 2).

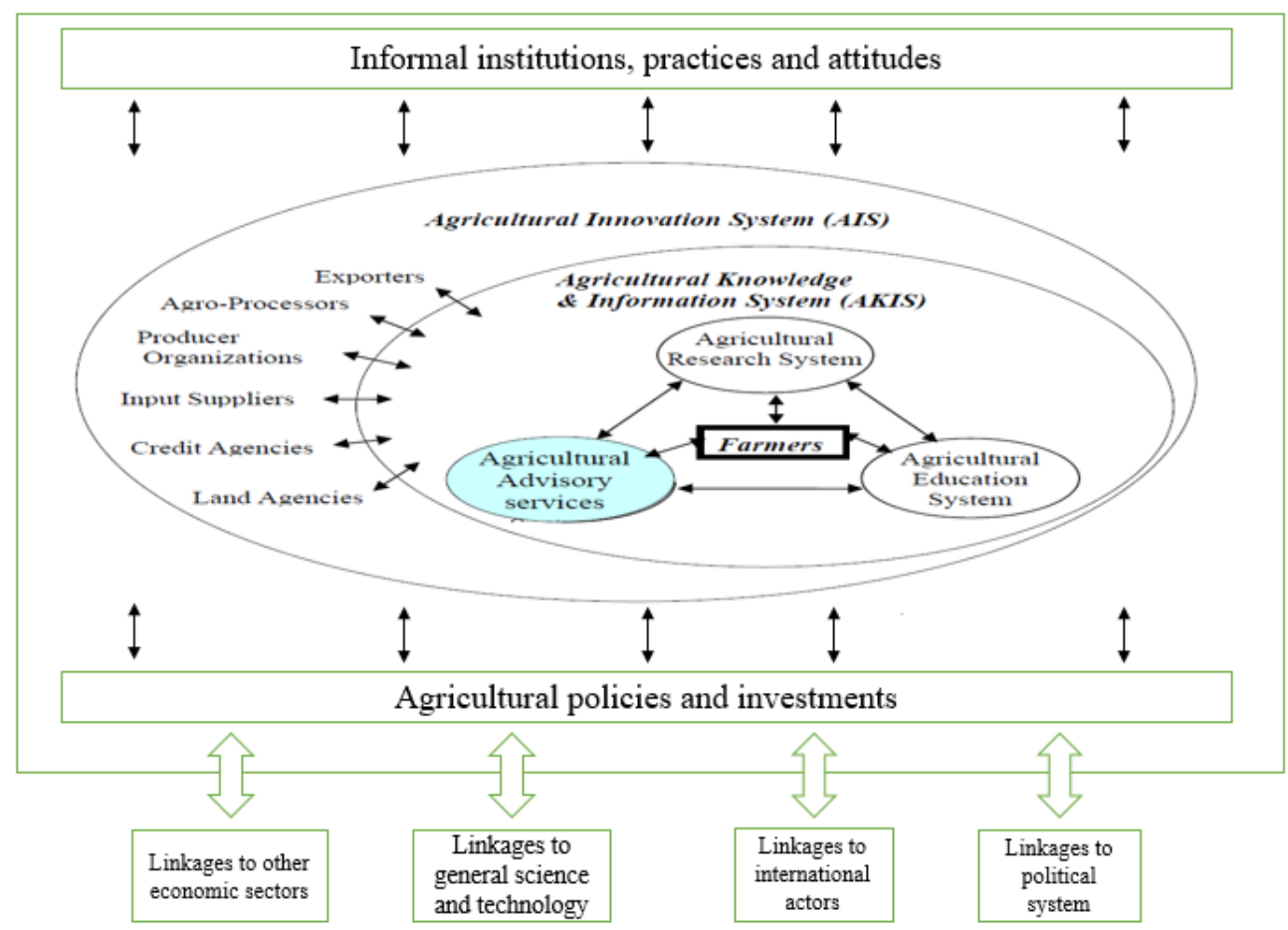

Figure 2. Agricultural advisory services as part of the agricultural innovation system (AIS). Inspired from [58], and [59] adapted from [60]. 


\section{Knowledge Circulation in Relation to P-Related Agricultural BMPs}

As stated earlier, agricultural non-point source pollution is a major water quality concern. In order to reduce $\mathrm{P}$ losses from agricultural lands in a certain region, the processes and practices that control $\mathrm{P}$ losses must be understood. Without this knowledge, BMPs that are encouraged by public education, incentives, and regulations might be ineffective and even counter-productive. Government supports up to $95 \%$ of the total cost to implement the practices, but the adoption rate of BMPs is still low [61]. Also, there is a concern that farmers once having adopted may not continue these practices because some of these practices are costly and their adoption is voluntary [61].

The adoption of BMPs, including the 4 Rs approach (which stands for the right source, right rate, right time, and right place-an example of adaptive management), is an incentive based approach as a cost-share percentage paid by the federal government (e.g., Vollmer-Sanders et al. [62]. While the theoretical literature states that incentive based policies can achieve a higher adoption rate compared to traditional regulations (e.g., technological or performance standards), the practical literature sometimes shows otherwise. Benham et al. [63] undertook a comparative analysis of BMPs adoption between Virginia's Chesapeake Bay Basin and Southern Rivers Watershed, and found out that BMPs implementation was greater in the Bay basin even though farmers' characteristics and attitudes toward pollution and water quality were very similar. Most of the farmers in that region implemented non-cost share BMPs. But in total, cost-share and non-cost share BMPs were higher in the Bay basin mainly due to more focused, long-term BMP educational programs (Benham et al., 2007). Similarly, Hall et al. [61] found education to have a positive significant effect in the longevity of adopting a certain BMP practice, compared to age and income-share. On the other hand, Filson et al. [64] analyzed 481 landowners' self-administered questionnaires from surveys in five southern Ontario watersheds and found what farmers wanted the most was government financial support for implementing BMPs voluntarily. In addition, the authors showed that farm size along with revenue through farm sales were more significant when farmers' age, education, and gender were taken into account [64].

As we can observe, the determinants of adoption of BMPs may well be different from the determinants for all types of agricultural innovation [65]. In addition, it appears that the causes of adoption (e.g., awareness and attitudinal questions) of agricultural best management practices are best understood when they are place-based [66]. For instance, Knowler and Bradshaw [67] summarized the adoption of conservation tillage worldwide, but they were not able to universally explain its adoption. However, by looking at conservation easements across the world, the most significant social factors were age, tenure, and knowledge of and attitudes towards these programs [68]. Using a vote count methodology, Prokopy et al. [65] reviewed 25 years of literature on the adoption of agricultural BMPs in the United Sates to examine the general trends in the factors (along with their sub-categories) leading to adoption of different types of BMPs. The general finding was that education levels, capital, income, farm size, access to information, positive environmental attitudes, environmental awareness, and utilization of social networks, are usually considered variables that are positively associated with adoption rates (Table 3, Prokopy et al. [65]).

The results of Prokopy et al. [65], who summarized the adoption literature in the US for 15 years from 1982 to 2007, also showed that the majority of the studies have focused on soil, nutrient and pest management practices, and not enough on other types of practices such as water and livestock management. In addition, Prokopy et al. [65] found that the theoretical basis in the BMP adoption literature often lacks the inclusion of the categories of awareness and attitudes, along with their sub-categories. Unlike attitude and measures of awareness, farmer age and education are included in several studies [65]. However, Prokopy et al. [65] stressed the fact that awareness of an issue alone is not enough to predict behavior. Moreover, land tenure and land proximity to rivers were rarely taken into account, suggesting the need for their inclusion in future studies [65]. The authors also reported that farmers who received adoption payments in the past would not continue to adopt new practices consistently. The reason for this is that farmers either believe that their land is in good condition 
(hence there is no need to keep maintaining it) or they believe that obstacles to future participation will be very high [65].

Table 3. Social factors that lead to positive adoption rates according to Prokopy et al. [65].

\begin{tabular}{|c|c|c|}
\hline Category & Sub-Category & Adoption Rate \\
\hline \multirow{5}{*}{ Capacity } & Education (farmer education or training) & + \\
\hline & Capital (measure of investment into the farm, excluding acres) & + \\
\hline & Income (measure of wealth, such as crop value, ... ) & + \\
\hline & Farm size (number of acres farmed) & + \\
\hline & $\begin{array}{l}\text { Social networks (connectivity to agency personnel, networking capacity } \\
\text { in the agri-business sector, and interaction with neighbouring farms as } \\
\text { well as major organizations) }\end{array}$ & + \\
\hline \multirow{4}{*}{ Environmental Attitudes } & Adoption payments (for participating in conservation programs) & + \\
\hline & Farm succession (farm will be taken over by a family member) & + \\
\hline & Farmer's perception of the current quality of the environment & + \\
\hline & Willingness to take risks & + \\
\hline \multirow{3}{*}{ Environmental Awareness } & Cause (understanding how agriculture can impact environmental quality) & + \\
\hline & Consequence (understanding the consequences of a degraded system) & + \\
\hline & $\begin{array}{l}\text { Knowledge (knowledge of general terms or facts related to } \\
\text { environmental quality as well as knowledge of non-point source (NPS) } \\
\text { programs or efforts }\end{array}$ & + \\
\hline
\end{tabular}

Baumgart-Getz et al. [66] used a statistical method, called meta-analysis, to summarize 31 social factors in the adoption literature over 25 years-from 1982 to 2007-in the United States and they found out that access to and quality of information (i.e., how the actions of individuals on their farm impact water quality rather than how agriculture can degrade water bodies in general), financial capacity, and being connected to agency or local networks of farmers of watershed groups, are the most important factors that have the biggest influence on adoption. On the other hand, the authors pointed out the fact that there have been several studies using different approaches to data collection, affecting the results and comparability of adoption studies (i.e., in relation to environmental awareness and farmer attitudes, which have been inconsistently used and measured in the literature; Baumgart-Getz et al. [66]. In addition, their results showed that the 31 social factors only have a small influence on BMP adoption when assessed individually. Instead, effective BMP adoption efforts should combine complementary social factors together (e.g., using networks to implement extension efforts and disseminating information).

To conclude, it seems that knowledge circulation regarding BMPs is linear and centralized most of the time. However, there are cases where the source of ideas has been systemic such as the case of the 4Rs nutrient stewardship, where there is a central focus on adaptive management including the involvement of multiple stakeholders, including the interaction of nutrient-service providers and users. However, it is still not meaningfully effective since the 4Rs nutrient stewardship program is still heavily subsidized. Moreover, the literature exploring factors that lead to producer's voluntary adoption has not generally examined the specific attributes of BMPs (seen in Rogers, 2003; Reimer et al. [36,69]), which may ultimately affect acceptability to farmers and hence adoption. Further, it seems that many studies that focus on understanding farmer's behavior based on quantitative socio-economic demographics, attitudes and awareness, are inconsistent. As a result, understanding the motive of a farmer is a plus (e.g., Reimer et al.; Wallander et al. [70,71]).

\section{Conclusions}

This article addresses the social factors that influence farmers' adoption decisions of environmentally beneficial production practices (BMPs) to reduce phosphorus losses which find their way into surface water and degrade the quality of those surface water resources. The intended focus of the analysis 
is on the effects of farm practices on phosphorus concentrations in Lake Erie, which, in recent years, has experienced poor water quality levels after water quality had improved substantially from the 1970s. It analyzes the adoption of structural BMPs that plays an important role in mitigating phosphorous runoff from croplands and livestock. It first starts by reviewing case studies that used modeling land management practices on watershed yields in relation to climate change to show that the adoption of structural BMPs is still limited. It also shows that this argument is not so strong in the social component of the literature on BMPs adoption, given that such literature is conflicting and often lacking a strong reason why BMPs adoption is still limited. Consequently, this article adds the resilience and agricultural innovation perspectives to better inform us on the limited adoption of BMPs while bringing some insights to the issue. As we have seen, cost-share programs are not the main incentives for farmers to adopt such practices. There are other important factors that affect such decisions, such as age, education level, farm size, as well as other factors. It appears that there is a lack of research with regard to the determinants that affect the farmer's decision-making environment, especially in relation to BMPs adoption. Moreover, there is still a lack of research on the economic perspective on the abatement costs of using BMPs to reduce excess phosphorous, including on and off-farm benefits of such practices.

Furthermore, problems in agriculture are multi-dimensional, uncertain, and operate at multiple scales. Hence the need for holistic and interdisciplinary approaches. Given that there is not enough adoption of P-runoff related BMPs, what the resilience lens can bring to this issue is twofold: (1) at the theoretical level (systems thinking and learning); and (2) at the empirical level (adaptive management, including adaptive governance and co-management, starting with stakeholder engagement). Above all, it is systems thinking and adaptive management that stand out most clearly, as the two main umbrellas of the resilience lens (Figure 3). Stakeholder involvement and participatory research are very crucial in developing practices that will be adopted at the local community level (e.g., appropriate forms of co-construction approaches as stated in Bryant et al. (2016), Akkari and Bryant (2016), and Akkari et al. (2017) [72-74]). At the individual farm-level and in order to have a successful adoption of a BMP practice, systems thinking happens when farmers have integrated conservation and production plans. Adaptive management is a way of working with the low decidability of complex systems $[75,76]$. It realizes that human behavior is a part of ecosystems. It is also a part of systems thinking (Figure 3). Therefore, a systemic capacity to innovate is required within a complex and adaptive system like an AIS [77] (Leeuwis et al., 2014). Indeed, systems thinking and adaptive management have been the two main paradigm shifts in the recent resilience and innovation literature from the "one-size-fits-all" approach. However, in terms of integration of both social and ecological aspects, an AIS framework (such as the HES framework) needs to integrate at least generally the ecological effects of the social system as seen in Figure 3. This is where the resilience lens is especially useful. Indeed, socio-ecological resilience encompasses the four characteristics mentioned by $\mathrm{O}^{\prime}$ Connell et al. [23]. It is increasingly being treated as a general approach that addresses issues about the dynamics of systems, at different scales, that are not addressed by other theories, approaches, or frameworks $[78,79]$. The ability to innovate (and be adaptive) is the key for enhancing resilience, and is often related to collective action, coordination, and the exchange of knowledge among diverse actors. Innovation is the application of knowledge of all types to achieve desired socio-economic and environmental outcomes. It extends beyond knowledge creation to include the factors that affect the demand for and use of this knowledge. The innovation systems approach is attractive not only because it offers a holistic explanation of how knowledge is produced, diffused and utilized, but because it also emphasizes the actors that have become increasingly important in agricultural development such as agricultural advisory services in some territories. 


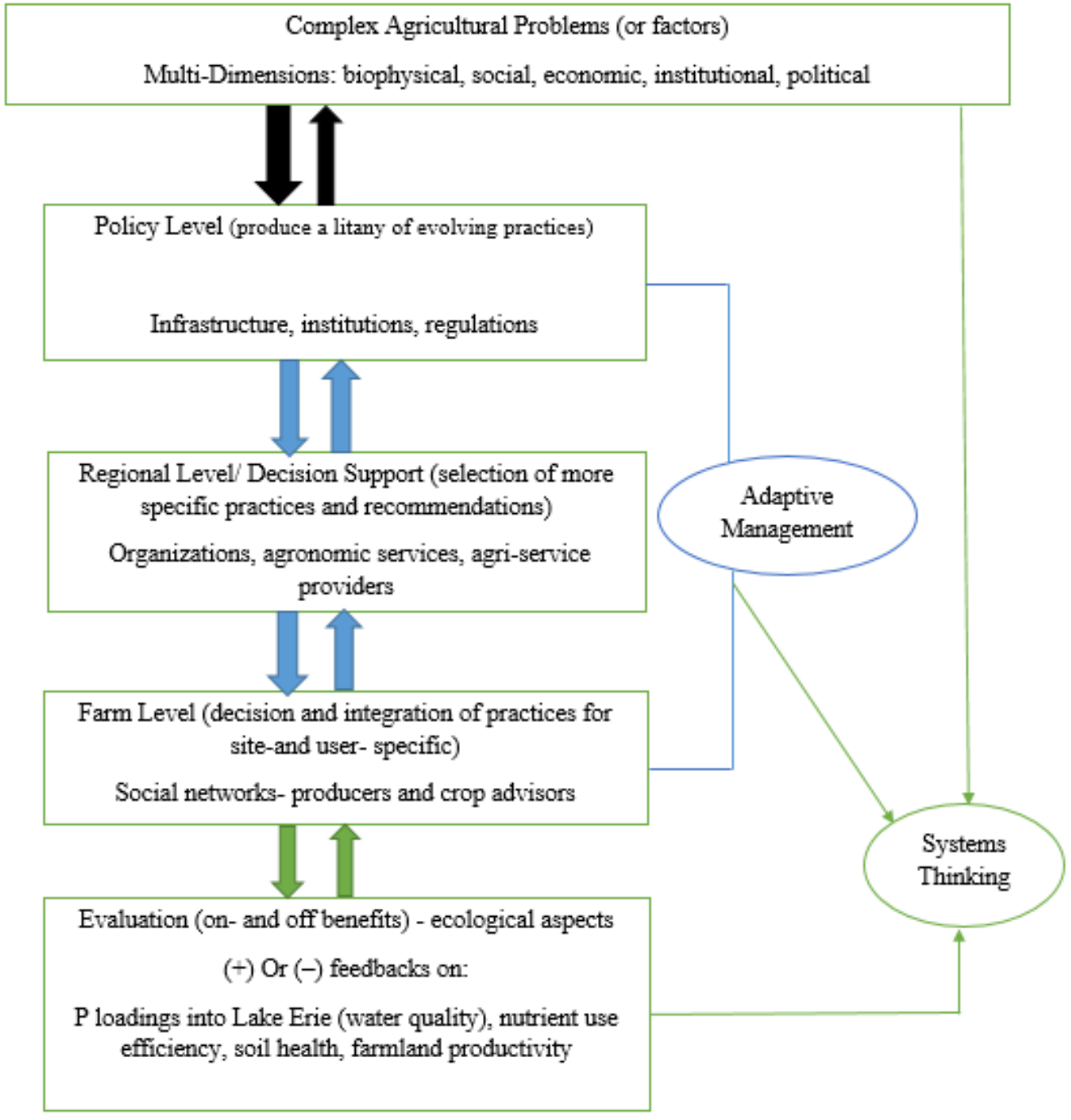

Figure 3. Adaptive management as part of systems thinking.

Acknowledgments: Special thanks go to Johanna Wandel and Merrin Macrae, at the University of Waterloo, for the initiation of this research topic. The authors would also like to thank the anonymous reviewers for their insightful comments. This research did not receive any specific grant from funding agencies in the public, commercial, or not-for-profit sectors.

Author Contributions: C.A. acquired, cleaned and analyzed the data and wrote and edited the manuscript. C.R.B. edited and revised the manuscript.

Conflicts of Interest: The authors declare that they have no competing interests.

\section{References}

1. Smith, D.R.; Francesconi, W.; Livingston, S.J.; Huang, C. Phosphorus losses from monitored fields with conservation practices in the Lake Erie Basin, USA. Ambio 2015, 44 (Suppl. 2), 319-331. [CrossRef] [PubMed]

2. Smith, D.R.; King, K.W.; Johnson, L.; Francesconi, W.; Richards, P.; Baker, D.; Sharpley, A.N. Surface Runoff and Tile Drainage Transport of Phosphorus in the Midwestern United States. J. Environ. Qual. 2015, 44, 495-502. [CrossRef] [PubMed]

3. Davis, T.W.; Berry, D.L.; Boyer, G.L.; Gobbler, C.J. The effects of temperature and nutrients on the growth and dynamics of toxic and non-toxic strains of Mycrocystis during cyanobacteria blooms. Harmful Algae 2009, 8, 715-725. [CrossRef] 
4. Bridgeman, T.B.; Chaffin, J.D.; Kane, D.D.; Conroy, J.D.; Panek, S.E.; Panek, P.M. Armenio From river to lake: Phosphorus partitioning and algal community compositional changes in Western Lake Erie. J. Gt. Lakes Res. 2012, 38, 90-97. [CrossRef]

5. Wynne, T.T.; Stumpf, R.P.; Tomlinson, M.C.; Fahnenstiel, G.L.; Dyble, J.; Schwab, D.J.; Joshi, S.J. Evolution of a cyanobacterial bloom forecast system in western Lake Erie: Development and initial evaluation. J. Gt. Lakes Res. 2013, 39, 90-99. [CrossRef]

6. Environment and Climate Change Canada. Phosphorous Levels in the Great Lakes. 2017. Available online: https:/ / www.ec.gc.ca/indicateurs-indicators/default.asp?lang=en\&n=A5EDAE56-1 (accessed on 20 April 2017).

7. Ulén, B.; Aronsson, H.; Bechmann, M.; Krogstad, T.; Oygarden, L.; Stenberg, M. Soil tillage methods to control phosphorus loss and potential sideeffects: A Scandinavian review. Soil Use Manag. 2010, 26, 94-107. [CrossRef]

8. $\quad$ King, K.W.; Williams, M.R.; Macrae, M.L.; Fausey, N.R.; Frankenberger, J.; Smith, D.R.; Kleinman, P.J.A.; Brown, L.C. Phosphorus transport in agricultural subsurface drainage: A review. J. Environ. Qual. 2015, 44, 467-485. [CrossRef] [PubMed]

9. International Joint Commission (IJC). A Balanced Diet for Lake Erie: Reducing Phosphorus Loadings and Harmful Algal Blooms. Available online: http:/ / www.ijc.org/files/publications/2014\%20IJC\%20LEEP\% 20REPORT.pdf (accessed on 4 July 2017).

10. Scavia, D.; Allan, J.D.; Arend, K.K.; Bartell, S.; Beletsky, D.; Bosch, N.S.; Brandt, S.B.; Briland, R.D.; Daloğlu, I.; DePinto, J.V.; et al. Assessing and addressing the re-eutrophication of Lake Erie: Central basin hypoxia. J. Gt. Lakes Res. 2014, 40, 226-246. [CrossRef]

11. King, K.W.; Williams, M.R.; Fausey, N.R. Contributions of Systematic Tile Drainage to Watershed-Scale Phosphorus Transport. J. Environ. Qual. 2015, 44, 486-494. [CrossRef] [PubMed]

12. Chung, E. CBCNEWS: Lake Erie's Algae Explosion Blamed on Farmers. 2014. Available online: http://www.cbc.ca/news/technology/lake-erie-s-algae-explosion-blamed-on-farmers-1.2729327 (accessed on 25 March 2017).

13. Fischer, M. Tile Drains a Major Path for Phosphorus Loss, Studies Find. American Society of Agronomy. 2014. Available online: https:/ / www.agronomy.org/science-news/tile-drains-major-path-phosphorus-lossstudies-find (accessed on 1 March 2017).

14. Ross, J.A.; Herbert, M.E.; Sowa, S.P.; Frankenberger, J.R.; King, K.W.; Christopher, S.F.; Tank, J.L.; Arnold, J.G.; White, M.J.; Yen, H. A synthesis and comparative evaluation of factors influencing the effectiveness of drainage water management. Agric. Water Manag. 2016, 178, 366-376. [CrossRef]

15. Keitzer, S.; Ludsin, S.A.; Sowa, S.; Annis, G.; Daggupati, P.; Froelich, A.M.; Herbert, M.E.; Johnson, M.V.; Yen, H.; White, M.J.; et al. Thinking outside the lake: How might Lake Erie nutrient management benefit stream conservation in the watershed? J. Gt. Lakes Res. 2016, 42, 1322-1331. [CrossRef]

16. Yen, H.; White, M.J.; Arnold, J.G.; Keitzer, S.C.; Johnson, M.-V.V.; Atwood, J.D.; Daggupati, P.; Herbert, M.E.; Sowa, S.P.; Ludsin, S.A. Western Lake Erie Basin: Soft-data-constrained, NHDPlus resolution watershed modeling and exploration of applicable conservation scenarios. Sci. Total Environ. 2016, 569, 1265-1281. [CrossRef] [PubMed]

17. Chiang, L.C.; Chaubey, I.; Hong, N.M.; Lin, Y.P.; Huang, T. Implementation of BMP strategies for adaptation to climate change and land use change in a pasture-dominated watershed. Int. J. Environ. Res. Public Health 2012, 9, 3654-3684. [CrossRef] [PubMed]

18. Agriculture and Agri-Food Canada. The Economics of Beneficial Management Practices. WEBs Fact Sheet \#8. AAFC No 11781E. 2012. Available online: http:/ / www.agr.gc.ca/resources/prod/doc/pdf/webs_epbh_ eco-eng.pdf (accessed on 15 April 2017).

19. Kim, S.-A.; Geffrey, G.P.; Krishna, P.P. The Effect of Economic Factors on the Adoption of Best Management Practices in Beef Cattle Production. Department of Agricultural Economics and Agribusiness. 2004. Available online: http:/ /ageconsearch.umn.edu/bitstream/34670/1/sp04ki05.pdf (accessed on 25 June 2017).

20. Rao, N.S.; Easton, Z.M.; Lee, D.R.; Steenhuis, T.S. Economic analysis of best management practices to reduce watershed phosphorous losses. J. Environ. Qual. 2012, 41, 855-864. [CrossRef] [PubMed]

21. Carpenter, S.R.; Walker, B.H.; Anderies, J.M.; Abel, N. From metaphor to measurement: Resilience of what to what? Ecosystems 2001, 4, 765-781. [CrossRef]

22. Walker, B.; Salt, D. Resilience Practice; Island Press: Washington, DC, USA, 2012. 
23. O'Connell, D.; Walker, B.; Abel, N.; Grigg, N. The Resilience, Adaptation and Transformation Assessment Framework: From Theory to Application. Available online: http://www.stapgef.org/sites/default/files / documents /CSIRO-STAP-Resilience-Adaptation-Transformation-Assessment-Framework-Report.pdf (accessed on 4 July 2017).

24. Hammond, B. Developing a Resilience Framework to Analyze Farmer Perspectives on Threat and Vulnerability to Catastrophic Events in Western Washington State. Available online: http:/ / cedar.wwu.edu/ cgi/viewcontent.cgi?article=1112\&context=wwuet (accessed on 4 July 2017).

25. Chapin, F.S.; Folke, C.; Kofinas, G.P. (Eds.) A Framework for Understanding Change. In Principles of Ecosystem Stewardship; Springer: New York, NY, USA, 2009.

26. Ostrom, E. A General Framework for Analyzing Sustainability of Social-Ecological Systems. Science 2009, 325, 419-422. [CrossRef] [PubMed]

27. Ostrom, E.; Janssen, M.A.; M, J. Anderies Going beyond panaceas. Proc. Natl. Acad. Sci. USA 2007, 104, 15176-15178. [CrossRef] [PubMed]

28. Scholz, R.W. Environmental Literacy in Science and Society: From Knowledge to Decisions; Cambridge University Press: New York, NY, USA, 2011.

29. Epstein, G.; Vogt, J.M.; Mincey, S.K.; Cox, M.; Fischer, B. Missing ecology: Integrating ecological perspectives with the social-ecological system framework. Int. J. Commons 2013, 7, 432-453. [CrossRef]

30. Binder, C.R.; Hinkel, J.; Bots, P.W.G.; Pahl-Wostl, C. Comparison of frameworks for analyzing social-ecological systems. Ecol. Soc. 2013, 18, 26. [CrossRef]

31. Fabinyi, M.; Evans, L.; Foale, S.J. Social-ecological systems, social diversity, and power: Insights from anthropology and political ecology. Ecol. Soc. 2014, 19, 28. [CrossRef]

32. Vogt, J.M.; Epstein, G.B.; Mincey, S.K.; Fischer, B.C.; Mccord, P. Putting the "E" in SES: Unpacking the ecology in the Ostrom social-ecological system framework. Ecol. Soc. 2015, 20, 55. [CrossRef]

33. Lisa, E.; Schipper, F.; Langston, L. A Comparative Overview of Resilience Measurements Frameworks: Analysing Indicators and Approaches. Available online: https://www.odi.org/sites/odi.org.uk/files/odiassets / publications-opinion-files/9754.pdf (accessed on 4 July 2017).

34. Rogers, E.M. Diffusion of Innovations, 4th ed.; The Free Press: New York, NY, USA, 1995.

35. Djalante, R.; Holley, C.; Thomalla, F. Adaptive Governance and Managing Resilience to Natural Hazards. Int. J. Disaster Risk Sci. 2011, 2, 1-14. [CrossRef]

36. Rogers, E.M. Diffusion of Innovations, 5th ed.; Free Press: New York, NY, USA, 2003.

37. Cabell, J.F.; Oelofse, M. An Indicator Framework for Assessing Agro-ecosystem Resilience. Ecol. Soc. 2012, 17, 13. [CrossRef]

38. Kofinas, G.P.; Chapin, F.S. Sustaining livelihoods and human well-being during socio-ecological change. In Principles of Ecosystem Stewardship; Chapin, F.S., Kofinas, G.P., Folke, C., Eds.; Springer: New York, NY, USA, 2009.

39. Berkes, F.; Folke, C. Back to the Future: Ecosystem Dynamics and Local Knowledge; Gunderson, L.H., Holling, C.S., Eds.; Panarchy: Understanding Transformations in Human and Natural Systems; Island Press: Washington, DC, USA, 2002.

40. Grigg, N.; Abel, N.; O'Connell, D.; Walker, B. Available online: http://www.stapgef.org/sites/default/ files/documents/CSIRO-STAP-Resilience-assessment-desktop-case-studies-in-Thailand-and-Niger.pdf (accessed on 4 July 2017).

41. Armitage, D.; Berkes, F.; Doubleday, N. Adaptive Co-Management: Collaboration, Learning, and Multi-Level Governance; UBC Press: Vancouver, BC, Canada; Toronto, ON, Canada, 2007.

42. Zerner, C. (Ed.) People, Plants, and Justice: The Politics of Nature Conservation; University Press: Columbia, NY, USA, 2000.

43. Colfer, C.J.P. The Equitable Forest: Diversity, Community, and Resource Management; Resources for the Future: Washington, DC, USA, 2005.

44. Young, O.R. Institutions and Environmental Change, Principal Findings, Applications and Research Frontiers. Available online: http://2007amsterdamconference.org/Downloads/AC2007_Young.pdf (accessed on 4 July 2017).

45. Folke, C.; Hahn, T.; Olsson, P.; Norberg, J. Adaptive governance of socio-ecological systems. Annu. Rev. Environ. Resour. 2005, 30, 441-473. [CrossRef] 
46. Kofinas, G.P. Adaptive co-management in socio-ecological governance. In Principles of Ecosystem Stewardship; Chapin, F.S., Kofinas, G.P., Folke, C., Eds.; Springer: New York, NY, USA, 2009.

47. Plummer, R.; FitzGibbon, J. Co-management of natural resources: A proposed framework. Environ. Manag. 2004, 33, 876-885. [CrossRef]

48. Bastakoti, R.C.; Shivakoti, G.P.; Lebel, L. Local Irrigation Management Institutions Mediate Changes Driven by External Policy and Market Pressures in Nepal and Thailand. Environ. Manag. 2010, 46, 411-423. [CrossRef] [PubMed]

49. Schut, M.; Rodenburg, L.; Klerkx, L.; van Ast, A.; Bastianns, L. Systems approaches to innovation in crop protection. A systematic literature review. Crop Prot. 2014, 56, 98-108. [CrossRef]

50. Pant, L.P. Critical systems of learning and innovation competence for addressing complexity in transformations to agricultural sustainability. Agroecol. Sustain. Food Syst. 2013, 38, 336-365. [CrossRef]

51. Botta, G.F.; Tolón-Becerra, A.; Lastra-Bravo, X.; Tourn, M.C. A research of the environmental and social effects of the adoption of biotechnological practices for soybean cultivation in Argentina. Am. J. Plant. Sci. 2011, 2, 359-369. [CrossRef]

52. Hansen, T. Geography of Innovation. Available online: http://www.oxfordbibliographies.com/view/ document/obo-9780199874002/obo-9780199874002-0131.xml (accessed on 4 July 2017).

53. Klerkx, L.; van Mierlo, B.; Leeuwis, C. Evolution of Systems Approaches to Agricultural Innovation: Concepts, Analysis and Interventions, Farming Systems Research into the 21st Century: The New Dynamic. Available online: https://link.springer.com/chapter/10.1007\%2F978-94-007-4503-2_20 (accessed on 4 July 2017).

54. Daouda, O.; Bryant, C.R. Analysis of Power Relations among Actors and Institutions in the Process of Agricultural Adaptation to Climate Change and Variability from the Diffusion of Innovations Perspective. Available online: https://www.researchgate.net/publication/305391812_Analysis_of_Power_Relations_ among_Actors_and_Institutions_in_the_Process_of_Agricultural_Adaptation_to_Climate_Change_and_ Variability_from_the_Diffusion_of_Innovations_Perspective (accessed on 4 July 2017).

55. Schut, M.; Klerkx, L.; Rodenburg, J.; Kayeke, J.; Hinnou, L.C.; Raboanarielina, C.M.; Bastiaans, L. RAAIS: Rapid Appraisal of Agricultural Innovation Systems (Part I). A diagnostic tool for integrated analysis of complex problems and innovation capacity. Agric. Syst. 2015, 132, 1-11. [CrossRef]

56. Sunding, D.; Zilberman, D. The Agricultural Innovation Process: Research and Technology Adoption in a Changing Agricultural Sector. Handb. Agric. Econ. 2000. Available online: http://www.cpahq.org/cpahq/ cpadocs/Agricult\%20Innovation.pdf (accessed on 23 April 2017).

57. Rodima-Taylor, D.; Olwig, M.F.; Chhetri, N. Adaptation as innovation, innovation as adaptation: An institutional approach to climate change. Appl. Geogr. 2012, 33, 107-111. [CrossRef]

58. Rivera, M.W.; Alex, G.; Hanson, J.; Birner, R. Enabling Agriculture: The Evolution and Promise of Agricultural Knowledge Frameworks. In Proceedings of the 2006 Conference of the Association for International Agricultural Education and Extension (AIAEE), Clearwater Beach, FL, USA, 14-18 May 2006.

59. Spielman, D.; Birner, R. How Innovative Is Your Agriculture? Using Innovation Indicators and Benchmarks to Strengthen National and Agricultural Innovation Systems; World Bank: Washington, DC, USA, 2008.

60. Arnold, E.; Bell, M. Some New Ideas about Research and Development; Science and Technology Policy Research/Technopolis: Copenhagen, Denmark, 2001.

61. Hall, L.M.; Paudel, K.P.; Gauthier, W.M.; Westra, J.V. Decision to adopt and exit best management practices by dairy farmers. Department of Agricultural Economics and Agribusiness. Louisiana State University. In Proceedings of the American Agricultural Economics Association Annual Meeting, Oregon, Portland, 29 July-1 August 2007.

62. Vollmer-Sanders, C.; Allmen, A.; Busdeker, D.; Moody, L.B.; Stanley, W.G. J. Gt. Lakes Res. 2016, 42, $1395-1402$. [CrossRef]

63. Benham, B.L.; Braccia, A.; Mostaghimi, S.; Lowery, J.B.; McClellan, P.W. Comparison of Best Management Practice Adoption between Virginia's Chesapeake Bay Basin and Southern Rivers Watersheds. Available online: https://www.researchgate.net/profile/Saied_Mostaghimi/publication/251852639_Comparison_of_ Best_Management_Practice_Adoption_Between_Virginia\%27s_Chesapeake_Bay_Basin_and_Southern_ Rivers_Watersheds/links/00b7d52dbf9367a945000000/Comparison-of-Best-Management-PracticeAdoption-Between-Virginias-Chesapeake-Bay-Basin-and-Southern-Rivers-Watersheds.pdf (accessed on 4 July 2017). 
64. Filson, G.C.; Sethuratnam, S.; Adekunle, B.; Lamba, P. Beneficial Management Practice Adoption in Five Southern Ontario Watersheds. J. Sustain. Agric. 2009, 33, 229-252. [CrossRef]

65. Prokopy, L.S.; Floress, K.; Klotthor-Weinkauf, D.; Baumgart-Getz, A. Determinants of Agricultural Best Management Practice Adoption: Evidence from the Literature. J. Soil Water Conserv. 2008, 63, 300-311. [CrossRef]

66. Baumgart-Getz, A.; Prokopy, L.S.; Floress, K. Why farmers adopt best management practice in the United States: A meta-analysis of the adoption literature. J. Environ. Manag. 2012, 96, 17-25. [CrossRef] [PubMed]

67. Knowler, D.; Bradshaw, B. Farmers' adoption of conservation agriculture: A review and synthesis of the recent literature. Food Policy 2007, 32, 25-48. [CrossRef]

68. Kabii, T.; Horwitz, P. A review of landholder motivations and determinants for participation in conservation covenanting programmes. Environ. Conserv. 2006, 33, 11-20. [CrossRef]

69. Reimer, A.P.; Weinkauf, D.K.; Prokopy, L.S. The influence of perceptions of practice characteristics: An examination of agricultural best management practice adoption in two Indiana watersheds. J. Rural Stud. 2012, 28, 118-128. [CrossRef]

70. Reimer, A.P.; Thompson, A.W.; Prokopy, L.S. The multi-dimensional nature of environmental attitudes among farmers in Indiana: Implications for conservation adoption. Agric. Human Values 2012, 29, $29-40$. [CrossRef]

71. Wallander, S.; Aillery, M.; Hellerstein, D.; Hand, M. The Role of Conservation Programs in Drought Risk Adaptation. Available online: https://www.ers.usda.gov/webdocs/publications/45066/37191_err-148summary.pdf?v=41744 (accessed on 4 July 2017).

72. Bryant, C.R.; Akkari, C.; Bousbaine, A.D.; Daouda, O.; Delusca, K.; Épulé, T.E.; Drouin-Lavigne, C. The roles of governments and other actors in adaptation to climate change and variability: The examples of agriculture and coastal communities. AIMS Environ. Sci. 2016, 3, 326-346. [CrossRef]

73. Akkari, C.; Bryant, C.R. The co-construction approach to developing adaptation strategies in the face of climate change and variability: A Conceptual Framework. Agric. Res. 2016, 5, 162-173. [CrossRef]

74. Akkari, C.; Bryant, C.R.; Marois, C. The co-construction of agricultural policies as a bottom-up adaptation strategy to climate change and variability (CCV) in the Regional County Municipality (RCM) of Haut-Richelieu, Québec. J. Agric. Stud. 2017, 5, 141-162. [CrossRef]

75. Klerkx, L.; Aarts, N.; Leeuwis, C. Adaptive management in agricultural innovation systems: The interactions between innovation networks and their environment. Agric. Syst. 2010, 103, 390-400. [CrossRef]

76. Westley, F.; Olsson, P.; Folke, C.; Homer-Dixon, T.; Vredenburg, H.; Loorbach, D.; Thompson, J.; Nilsson, M.; Lambin, E.; Sendzimir, J.; et al. Tipping toward sustainability: Emerging pathways of transformation. Ambio 2011, 40, 762-780. [CrossRef] [PubMed]

77. Leeuwis, C.; Schut, M.; Waters-Bayer, A.; Mur, R.; Atta-Krah, K.; Douthwaite, B. Capacity to Innovate from a System-CRP Perspective. Available online: http:/ / www.prolinnova.net/sites/default/files/documents / news /2014/capacitytoinnovatebrieffinal_010514.pdf (accessed on 4 July 2017).

78. Anderies, J.M.; Walker, B.H.; Kinzig, A.P. Fifteen weddings and a funeral: Case studies and resilience-Based management. Ecol. Soc. 2006, 11, 21. [CrossRef]

79. Lundholm, C.; Plummer, R. Resilience and learning: A conspectus for environmental education. Environ. Educ. Res. 2010, 16, 475-491. [CrossRef]

(C) 2017 by the authors. Licensee MDPI, Basel, Switzerland. This article is an open access article distributed under the terms and conditions of the Creative Commons Attribution (CC BY) license (http://creativecommons.org/licenses/by/4.0/). 